\title{
Virus antibody in synovial fluid of rheumatoid and control patients
}

\author{
FRED STANFORD
}

From the Department of Microbiology, The Queen's University of Belfast, Grosvenor Road, Belfast, Northern $\vec{\circ}$ Ireland

Local increases in the antibody concentration of tissue fluids usually indicates the presence of the antigen. Thus Connolly, Allen, Hurwitz, and Millar (1967) showed higher titres of measles antibody in the CSF of patients with measles-induced subacute sclerosing panencephalitis compared to controls. Likewise, the CSF to serum ratio of antibody for measles was higher than for other viruses within this group of patients. If rheumatoid arthritis is caused by a common virus, then increased concentrations of virus specific antibody in the synovial tissue would indicate the responsible virus. One way to test this is to compare the ratio of synovial fluid to serum antibody titres for different viruses within the rheumatoid group of patients and also to compare this ratio in rheumatoid and control patients.

Antigen-antibody-like complexes containing rheumatoid factor and low concentrations of complement have been described in rheumatoid synovial fluid (Hannestad, 1968; Zvaifler, 1970). Since low concentrations of complement usually indicate its consumption during antigen and antibody interaction, a relationship between complement and virus specific antibody titres may indicate if a particular virus is involved in the complex.

In this study both the above methods have been used to look for evidence of virus infection in 28 rheumatoid and seventeen control patients.

\section{Methods}

There were 28 patients with rheumatoid arthritis, eight with osteoarthritis, five with torn menisci, three with psoriasis, and one with gout. There were eleven females and seventeen males in the rheumatoid group (mean age 51) and five females and twelve males in the control group (mean age 39).

Samples of venous blood and knee synovial fluid were taken simultaneously. Serum and synovial fluid were stored at $-20^{\circ} \mathrm{C}$ until ready for use. An aliquot of each was stored at $-70^{\circ} \mathrm{C}$ for complement estimation.

Because the viscosity of synovial fluid prevents rapid mixing of the reagents during antibody estimation, samples of both serum and synovial fluid were treated with $\rightarrow$ hyaluronidase (Hyalase) for 1 hour at $37^{\circ} \mathrm{C}$ before use.

Irrespective of rheumatoid factor content, all samples $\stackrel{\frac{1}{N}}{N}$

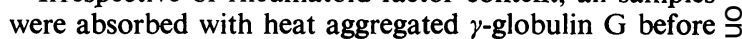
antibody estimation (Stanford, 1972).

Complement fixing (CF) antibody against herpes sim- $\subseteq$ plex, measles, and mumps viruses was measured by the method of Bradstreet and Taylor (1962), while rubella $\vec{\varphi}$ haemagglutination inhibition (HAI) antibody was measured by the method of Schmidt and Lennette (1970) using pigeon erythrocytes after the removal of $\beta$-lipoprotein by manganese and heparin precipitation.

Immunoglobulin $\mathbf{M}$ concentration was measured by radial diffusion for 24 hours at $37^{\circ} \mathrm{C}$ using Hyland's plates. Rheumatoid factor was estimated using a latex method (Hyland's RA test).

Total haemolytic complement was measured at $37^{\circ} \mathrm{C}$ using sheep erythrocytes sensitized with horse haemolysin as the indicator. The third component of complement (C3) was estimated by radial diffusion using Hyland's plates.

Student's ' $t$ '-test was used to assess the differences between synovial fluid and serum geometric mean titres or $\overline{0}$ the ratios of these titres. The probability $(\mathrm{P})$ was calculated from the results. A correlation coefficient $(r)$ was estimated 8 for both the serum to synovial fluid comparisons and the comparisons within the synovial fluid. The significance 0 was calculated from the standard error.

\section{Results}

The relationship between serum and synovial fluid antibody titres for herpes simplex CF and rubella HAI antibody is shown in Figs 1 and 2, respectively. $\omega$ Those for measles and mumps CF antibody are similar. Analysis of these results (Table I) shows thatco the correlation between serum and synovial fluid anti- $\frac{\varnothing}{\varnothing}$ body titres is significant for herpes simplex, measles, $\stackrel{?}{+}$ and mumps CF antibody and rubella $\mathrm{HAI}$ antibody $\underline{T}$ in rheumatoid and control patients. The correlation between serum and synovial fluid for IgM macroglobulin is only significant for the rheumatoid patients.

The value for the ratio of virus antibody and $\operatorname{IgM}$ macroglobulin between synovial fluid and serum is 


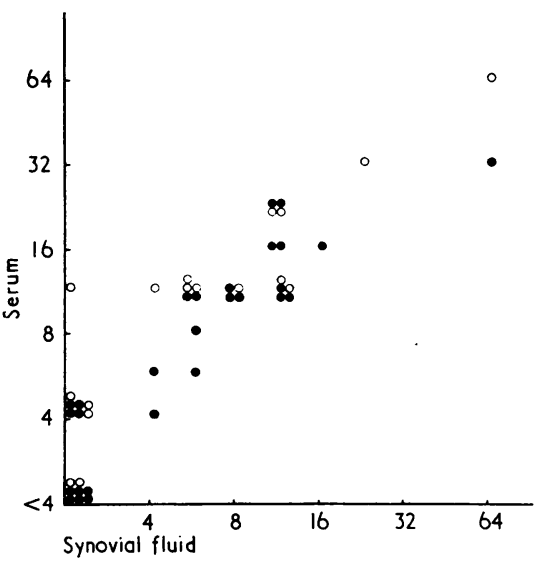

FIG. 1 Comparison of serum and synovial fluid herpes simplex CF antibody titres in rheumatoid (०) and control (O) patients

higher in the rheumatoid patients than the control, though the ratio for rubella HAI antibody does not reach significance (Table II). Within the rheumatoid group there is no significant difference $(P>0.05)$ between the values for the ratio of synovial fluid to serum antibody against herpes simplex, measles, mumps, or rubella virus.

Table III shows that for rheumatoid synovial fluid there is no significant correlation between the titre of rheumatoid factor, total haemolytic complement or $\mathrm{C} 3$, and any of the four virus antibodies tested. There was also no correlation between these variables in rheumatoid serum and control serum or synovial fluid.

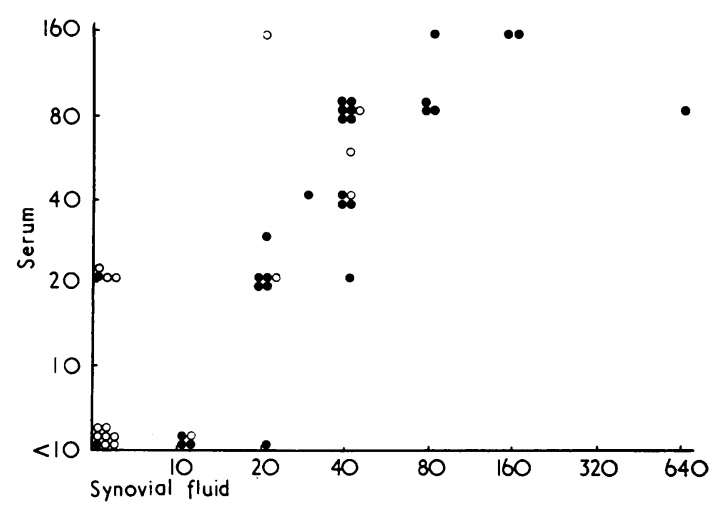

FIG. 2 Comparison of serum and synovial fluid rubella HAI antibody titres in rheumatoid (๑) and control (0) patients

\section{Discussion}

The positive correlation between the higher serum and lower synovial fluid titres for virus antibody in both rheumatoid and control patients suggests that the synovial fluid antibody is predominantly derived from the blood, Though there is a higher value for the ratio of synovial fluid to serum virus antibody in rheumatoid patients than in controls, it is unlikely that there is simultaneous infection with herpes simplex, measles, mumps, and rubella viruses in these joints. Since the value for the ratio of antibody between the two body fluids is similar for the four viruses in the rheumatoid patients, the difference

Table I Correlation coefficient (r) for values of virus antibody titres in serum and synovial fluid of 28 rheumatoid and 17 control patients

\begin{tabular}{|c|c|c|c|c|}
\hline \multirow[b]{2}{*}{ Antibody } & \multicolumn{2}{|c|}{ Rheumatoid serum vs. synovial fluid } & \multicolumn{2}{|c|}{ Control serum vs. synovial fluid } \\
\hline & r value & Significance & $\mathrm{r}$ value & Significance \\
\hline $\begin{array}{l}\text { Herpes simplex CF antibody } \\
\text { Measles CF antibody } \\
\text { Mumps CF antibody } \\
\text { Rubella HAI antibody } \\
\text { Total IgM }\end{array}$ & $\begin{array}{l}0.99 \\
0.93 \\
0.74 \\
0.68 \\
0.62\end{array}$ & $\begin{array}{l}P<0.001 \\
P<0.001 \\
P<0.001 \\
P<0.001 \\
P<0.001\end{array}$ & $\begin{array}{l}0.95 \\
0.87 \\
0.67 \\
0.71 \\
0.46\end{array}$ & $\begin{array}{l}P<0.001 \\
P<0.001 \\
P<0.05 \\
P<0.05 \\
P>0.05\end{array}$ \\
\hline
\end{tabular}

Table II Comparison of the $\log _{10}$ geometric mean antibody and IgM ratios between synovial fluid and serum for 28 rheumatoid and 17 control patients

Mean antibody synovial fluid to serum ratio

\begin{tabular}{|c|c|c|c|}
\hline & & & \\
\hline Antibody & Rheumatoid & Control & Significance \\
\hline $\begin{array}{l}\text { Herpes simplex CF antibody } \\
\text { Measles CF antibody } \\
\text { Mumps CF antibody } \\
\text { Rubella HAI antibody } \\
\text { Total IgM }\end{array}$ & $\begin{array}{l}0.9839 \\
0 \cdot 8781 \\
0 \cdot 8716 \\
0.9995 \\
0 \cdot 8200\end{array}$ & $\begin{array}{l}0.9036 \\
0 \cdot 7489 \\
0 \cdot 6397 \\
0 \cdot 8712 \\
0 \cdot 7160\end{array}$ & $\begin{array}{l}P<0.001 \\
P<0.05 \\
P<0.01 \\
P<0.2 \\
P<0.02\end{array}$ \\
\hline
\end{tabular}


Table III Correlation coefficient (r) for herpes simplex, measles, and mumps CF antibody and rubella $H A I$ antibody with total haemolytic complement, the third component of complement (C3), and rheumatoid factor titre in 28 rheumatoid synovial fuids

\begin{tabular}{|c|c|c|c|c|c|c|}
\hline \multirow[b]{2}{*}{ Antibody } & \multicolumn{2}{|c|}{$\begin{array}{l}\text { Total haemolytic } \\
\text { complement }\end{array}$} & \multicolumn{2}{|l|}{$C 3$} & \multicolumn{2}{|c|}{ Rheumatoid factor } \\
\hline & $r$ & Significance & $\mathrm{r}$ & Significance & $\mathrm{r}$ & Significance \\
\hline $\begin{array}{l}\text { Herpes simplex CF antibody } \\
\text { Measles CF antibody } \\
\text { Mumps CF antibody } \\
\text { Rubella HAI antibody } \\
\text { Total IgM }\end{array}$ & $\begin{array}{l}+0.05 \\
-0.11 \\
+0.32 \\
+0.03 \\
+0 \cdot 10\end{array}$ & $\begin{array}{l}\text { NS } \\
\text { NS } \\
\text { NS } \\
\text { NS } \\
\text { NS }\end{array}$ & $\begin{array}{l}+0 \cdot 17 \\
+0 \cdot 04 \\
+0 \cdot 28 \\
+0 \cdot 18 \\
+0 \cdot 10\end{array}$ & $\begin{array}{l}\text { NS } \\
\text { NS } \\
\text { NS } \\
\text { NS } \\
\text { NS }\end{array}$ & $\begin{array}{l}-0.32 \\
-0.06 \\
-0.20 \\
+0.13 \\
+0.41\end{array}$ & $\begin{array}{l}\text { NS } \\
\text { NS } \\
\text { NS } \\
\text { NS } \\
\text { NS }\end{array}$ \\
\hline
\end{tabular}

NS $=$ P $>0.05$.

from controls is probably due to the general increase in permeability of the rheumatoid synovium to plasma proteins, including macroglobulins (Schur and Sandson, 1963).

Occasionally higher titres of rheumatoid factor or antinuclear factor are found in the synovial fluid than in the serum in rheumatoid patients (Hannestad and Mellbye, 1967; Solnica, Kahn, and de Sèze, 1968). Similarly, in this study there was an occasional patient with a higher synovial fluid than serum titre of rheumatoid factor or virus antibody. This may represent local antibody formation, but the effects upon the method of antibody estimation of differences in total protein concentrations between the two fluids should be considered, e.g. with rheumatoid factor the higher serum IgG concentrations may mask the presence of IgM rheumatoid factor (Bluestone, Goldberg, and Cracchiolo, 1969).

The present experiments show no correlation between the titres of CF antibody against herpes simplex, measles, and mumps viruses and either the synovial fluid complement or rheumatoid factor titres. Therefore, although antigen-antibody complexes have been described in rheumatoid synovial fluid containing rheumatoid factor (Hannestad and Mellbye, 1967) and in rheumatoid synovial cells containing complement (Vaughan, Barnett, Sobel, and Jacox, 1968), there is no evidence that these three virus antibodies are involved in the complexes. There is also no correlation between rubella HAI antibody and complement or rheumatoid factor, and this antibody would probably enter antigen-antibody complexes in parallel with the CF antibody.

Winchester, Agnello, and Kunkel (1969) found evidence from ultracentrifuge studies for the presence of immunoglobulins only in the rheumatoid synovial fluid complexes. From three rheumatoid synovial fluids I precipitated antigen-antibody-like complexes with rheumatoid factor by double diffusion in agar-

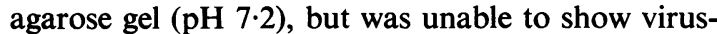
like particles by the use of negative staining electron microscopy in the precipitate.

\section{Summary}

Antibody against herpes simplex, measles, mumps, and rubella viruses has been measured in serum and synovial fluid from 28 rheumatoid and seventeen control patients. There was a higher value for the ratio of antibody between synovial fluid and serum in the rheumatoid than in the control patients for all four viruses. It is suggested that this difference between the two groups can be explained by increased passage of proteins, including antibody, from the blood to the synovial fluid in rheumatoid patients rather than by infection of the synovium by the viruses.

There is no evidence, from correlation studies between virus antibody titres and either complement or rheumatoid factor, for the uptake of any of these four antibodies into antigen-antibody complexes in the synovial fluid.

I am indebted to Professor K. B. Fraser and Dr. J. H. Connolly of the Department of Microbiology, The Queen's University of Belfast, and Dr. S. D. Roberts of the Royal Victoria Hospital, Belfast, for their encouragement and guidance throughout this study. The statistical analyses were kindly carried out by Dr. K. D. MacRae of the Department of Medical Statistics, The Queen's University of Belfast.

The author is in receipt of a research fellowship from the Royal Victoria Hospital, Belfast.

\section{References}

Bluestone, R., Goldberg, L. S., ANd Cracchiolo III, A. (1969) Lancet, 2, 878 (Hidden rheumatoid factor in seronegative nodular rheumatoid arthritis)

Bradstreet, C. M. P., And Taylor, C. E. D. (1962) Monthly Bull. Minist. Health (London), 21, 96 (Technique of complement-fixation test applicable to the diagnosis of virus diseases)

Connolly, J. H., Allen, I. V., Hurwitz, L. J., And Millar, J. H. D. (1967) Lancet, 1, 542 (Measles-virus antibody and antigen in subacute sclerosing panencephalitis) 
HANNESTAD, K. (1968) Clin. exp. Immunol., 3, 671 (Rheumatoid factors reacting with autologous native gamma Gglobulin and joint fluid and $\mathrm{G}$ aggregates)

—, AND MellbYe, O. J. (1967) Ibid., 2, 501 (Rheumatoid factor in synovial effusions: local reductions in consumption)

SolnICA, J., KAHN, M.-F., AND DE Sèze, S. (1968) Rev. Rheum., 635, 312 (Etudes immunologiques sur les liquides synoviaux)

Schmidt, N. J., AND Lennetre, E. H. (1970) Appl. Microbiol., 19, 491 (Variables of the rubella haemagglutination inhibition test system and their effect on antigen and antibody titres)

SChUr, P. H., AND SANDSON, J. (1963) Arthr. and Rheum., 6, 115 (Immunologic studies of the proteins of human synovial fluid)

StANFORd, F. (1972) Ann. rheum. Dis., 31, 330 (Comparison of complement-fixing antibody titres in patients with rheumatoid arthritis and matched controls)

Vaughan, J. H., Barnett, E. V., Sobel, M. V., and JaCox, R. F. (1968) Arthr. and Rheum., 11, 125 (Intracytoplasmic inclusions of immunoglobulins in rheumatoid arthritis and allied diseases)

Winchester, R. J., Agnello, V., AND KunKel, H. G. (1969) Ann. N. Y. Acad. Sci., 168, 195 (The joint-fluid and gamma G-globulin complexes and their relationship to intra articular complement diminution)

ZvAIFLER, N. J. (1970) Arthr. and Rheum., 13, 895 (Further speculation on the pathogenesis of joint inflammation in rheumatoid arthritis) 